\title{
Meningkatkan Keterampilan Dan Kreatifitas Santri Melalui Pengolahan Limbah Botol Plastik Menjadi Produk Siap Pakai
}

\author{
${ }^{1}$ Rosalinda Wiemar, ${ }^{2}$ Cama Juli Rianingrum, ${ }^{3}$ Susy Irma Adisurya \\ 1,2,3 Universitas Trisakti, Jakarta, Indonesia \\ E-mail: rosalinda wiemar@trisakti.ac.id
}

(Diterima: 21 September 2021; Direvisi: 23 Oktober 2021; Dipublikasikan: November 2021)

\begin{abstract}
ABSTRAK
Seiring perkembangan teknologi dan kebutuhan masyarakat, produksi makanan dan minuman dalam kemasan berkembang pesat. Berbagai bahan digunakan sebagai wadah, sebagian besar berbahan plastik, khususnya sebagai wadah minuman. Selain relatif murah, ringan, higienis, juga dapat diproses ke dalam bentuk yang estetik dan fungsional. Sayangnya, bahan ini sangat sulit terurai, sehingga berpotensi menjadi limbah yang merusak lingkungan serta mengganggu pemandangan. Santri pondok pesantren adalah generasi muda penerus bangsa, selain utamanya belajar ilmu agama namun turut pula bertanggung jawab menjaga dan menyelamatkan lingkungan. Dengan pembiayaan mandiri, Pondok pesantren Raudhatul Ishlah memiliki keterbatasan dana dalam pelaksanaan kegiatan santri sehari-hari. Untuk itu, pelatihan yang memberikan keterampilan tambahan akan sangat bermanfaat bagi para santri. Metode pelatihan diawali dengan ceramah dasar tentang warna, prinsip desain, gambaran karya yang akan dibuat dan mencoba mengembangkan kreatifitas para santri dengan memanfaatkan limbah botol plastik dipadu padan dengan bahan alam yang ada di sekitar pesantren. Dari pelatihan ini, santri mendapat tambahan pengetahuan dan keterampilan bermanfaat sehingga lebih kreatif dan produktif. sehingga dapat membantu santri mengisi waktu luang dengan kegiatan positif serta menghasilkan produk sesuai dengan kebutuhan para santri di pondok pesantren.
\end{abstract}

Kata Kunci: Botol Plastik; Keterampilan; Kreatifitas; Limbah; Santri.

\section{ABSTRACT:}

Along with the development of technology and the needs of society, the production of packaged food and beverages is growing rapidly. Various materials are used as containers, mostly plastic, especially as drink containers. Besides being relatively cheap, lightweight, hygienic, it is also easy to process into an aesthetic and functional form. Unfortunately, this material is very difficult to decompose, so it has the potential to become waste that damages the environment and disturbs the view. Students at Islamic boarding schools are the next generation of the nation. Apart from primarily studying religious knowledge, they are also responsible for protecting and saving the environment. With self-financing, Raudhatul Ishlah Islamic Boarding School has limited funds to carry out daily student activities. For this reason, training that provides additional skills will be very beneficial for the students. The training method begins with a basic lecture on colors, design principles, an overview of the work to be made and tries to develop the creativity of the students by utilizing plastic bottle waste combined with natural materials around the pesantren. From this training, students get additional useful knowledge and skills so that they are more creative and productive. so that it can help students fill their spare time with positive activities and produce products according to the needs of students in Islamic boarding schools.

Keywords: Plastic Bottle; Skills; Creativity; Waste; Students 


\section{PENDAHULUAN}

Kebutuhan pokok dalam hidup manusia adalah : sandang, pangan, dan papan. Meningkatnya berbagai kebutuhan manusia diikuti dengan berkembangnya teknologi untuk memenuhi tersebut, berbagai produktelah dihasilkan dengan pilihan jenis kualitas dan kuantitas yang beragam. Minum merupakan salah satu kebutuhan primer manusia, baik di tempat maupun dalam perjalanan. Kebutuhan pada kepraktisan menyebabkan banyak diproduksi air minum dalam berbagai kemasan. Salah satu kemasan terbanyak adalah dalam bentuk botol. Tingginya kebutuhan minuman dalam berbagai kemasan botol mengakibatkan banyaknya limbah bekas pakai. Material kemasan botol minum beragam jenisnya, seperti: kaca, kertas, plastik, dan lain-lain. Namun yang terbanyak adalah yang terbuat dari plastik. Limbah botol plastik sangat banyak terdapat dimana-mana. Penggunaan botol plastik memiliki dampak yang sangat buruk terhadap residu lingkungan, juga tidak sedap dipandang mata. Sampah sampah dari botol plastik menjadi penyumbang bencana banjir, karena mampu menyumbat aliran air sehingga membuat air menjadi meluap (Staf PKK, 2016).

Selain itu Botol plastik bisa menjadi ancaman terhadap bencana lingkungan. Hal tersebut karena proses penguraian botol plastik bisa memakan waktu 450 sampai 1.000 tahun. Sehingga sampah botol plastik akan menjadi limbah yang sangat berbahaya (Staf PKK, 2016). Agar botol plastik tidak terbuang percuma, diperlukan keterampilan untuk dapat memanfaatkannya. Untuk itu, sangat dibutuhkan pelatihan kepada masyarakat sebagai bekal untuk mengolah limbah botol plastik tersebut.

Dalam Focus Group Discussion (FGD) pemetaan model kurikulum pondok pesantren yang diselengggarakan oleh Kementerian Agama melalui Direktorat Pendidikan Diniyah dan Pondok Pesantren (PD Pontren) untuk tingkat Ula, Wustho, dan Ulya di Jakarta pada tanggal 18 Agustus 2020, Direktur PD Pontren Waryono mengungkapkan bahwa : "Kurikulum setidaknya memiliki tujuh fungsi". Dari tujuh fungsi pesantren tersebut terdapat empat fungsi yang sang at erat berkaitan dengan masyarakat,yaitu: 1.Fungsi kesesuaian, yaitu kesesuaian dengan kebutuhan dan zaman. Dalam hal ini kebutuhan masyarakat sekarang dan akan datang yang ada di sekitar pondok pesantren maupun tempat tinggal santri dapat menjadi peluang santri untuk dapat memberikan kontribusi, misalnya dengan mengolah limbah yang hasilnya juga dapat dimanfaatkan oleh masyarakat sendiri. 2. Fungsi integrasi, yaitu kurikulum harus disesuaikan dengan konteksnya, sehingga dapat membantu mendekatkan pengetahuan santri dengan masyarakat. Jika tidak, santri tidak dapat mengenali kebutuhan masyarakatnya dan akan menjadikan santri terasing serta berpotensi menjadi eksklusif. Keterampilan dan kreatifitas santri dalam mengolah limbah botol plastik dapat menjadi dalah satu jalan keluar kebutuhan masyarakat dalam berbagai aspek, antara lain ekonomi, sosial, budaya dan teknologi. 3.Berfungsi membantu menyiapkan santri untuk bisa berkiprah dan hidup di masyarakat. Selain pengetahuan agama yang utama, keterampilan dan kreatifitas santri dapat menjadi modal dan potensi santri saat terjun dalam masyarakat. 4. Fungsi diagnostik. Kurikulum harus bisa mendiagnosa perubahan yang terjadi di masyarakat. Pandemi mengajarkan masyarakat agar lebih pintar beradaptasi dengan keadaan. Dengan mampu mendiagnosa perubahan zaman, para santri dapat beradaptasi untuk bertahan hidup (Pojok Gusmen, 2020).

Dari empat fungsi tersebut di atas, tercermin pentingnya peran dan hubungan santri dalam masyarakat dan lingkungannya. Kemampuan santri berupa keterampilan dan kreatifitas 
diharapkan dapat membantu mewujudkan peran santri yang positif, khususnya berkaitan dengan limbah yang merusak lingkungan. Para santri sebagai remaja generasi masa depan, memiliki potensi dan tanggung jawab untuk merawat bumi, untuk itu dengan memiliki keterampilan dan kreatifitas memanfaatkan limbah, diharapkan dapat mendukung gerakan 3-R (reduce, reuse, recycle) sehingga dapat mengurangi sampah, khususnya sampah plastik. Reduce (mengurangi) adalah aktifitas mengurangi penggunaan barang-barang habis pakai yang dapat menghasilkan sampah. Tindakan yang dapat dilakukan sebagai pendukung program reduce antara lain: menghindari pemakaian dan pembelian produk yang menghasilkan sampah dalam jumlah besar; mengubah polamakan dengan mengkonsumsi makanan segar kurangi makanan/minuman instan atau lainnya dalam kemasan. Reuse (menggunakan kembali) adalah menggunakan kembali barang-barang yang masih bisa dipakai dan menghindari pemakaian sekali pakai guna memaksimalkan umur suatu barang. Tindakan reuse yang dapatdilakukanantara lain: memilih produk dengan kemasan yang dapat didaur ulang, menggunakan produk yang dapat diisiulang (refil), memanfaatkan gelas atau botol plastic untuk pot bibit, dan macam-macam kerajinan. Selanjutnya recycle (mendaurulang) adalah proses pengolahan sampah dengan memilah barang yang masih dapat digunakan kembali, atau dapat didaur ulang. Tidak semua jenis bahan dapat di daur ulang, namun tetap ada beberapa tindakan yang dapat dilakukan seperti: mengolah sampah organik menjadi kompos; menggunakan ranting, daun, akar kering sebagaikaryaseni yang bernilai tinggi (Bahraini, 2019)

Berdasarkan latarbelakang di atas, maka identifikasi masalah yang ditemukan adalah: 1. Bagaimana membuat produk dengan memanfaatkan limbah botol plastik dengan menggunakan peralatan sederhana. 2. Bagaimana memberikan kesadaran akan pentingnya keterampilan pengolahan dan pemanfaatan limbah botol plastik, sehingga memberi nilai tambah serta menjadi benda produk yang siap pakai. Dari identifikasi yang ditemukan, maka rumusan masalah yang akan diuraikan pada kegiatan pelatihan adalah agar dapat memberikan bimbingan pelatihan berupa pengetahuan tentang keterampilan mengolah limbah botol plastik, dapat memberikan jalan keluar agar pemanfaatan limbah botol plastik dapat menjadi produk siap pakai yang berguna bagi masyarakat dan lingkungannya, serta memberikan pelatihan kepada remaja sesuai dengan kebutuhan dan dapat meningkatkan kreatifitas peserta.

Penyelesaian permasalahan melalui kegiatan pelatihan, bertujuan untuk: 1 . Menambah pengetahuan dan keterampilan bagi peserta, yaitu dengan cara mengadakan pelatihan pemanfaatan limbah botol plastik menjadi produksiap pakai. 2. Dapat membantu mengisi waktu yang bermanfaat bagi para remaja sehingga lebih kreatif dan produktif. 3. Karya yang dihasilkan tidak saja bermanfaat bagi para santri, namun juga bagi masyarakat dan lingkungan sekitarnya, yaitu berupa nilai tambah pada limbah yang ke depannya dapat bernilai ekonomis sehingga menjadi tambahan penghasilan yang akan meningkatkan taraf hidup masyarakat.

\section{METODE}

Merujuk pada permasalahan yang ditemukan serta untuk mendapatkan hasil yang maksimal, maka dilakukan survey lapangan dengan teknik observasi pada lokasi pelaksanaan dan lingkungan sekitar. Dalam metode ini difokuskan pada aktivitas penghuni di dalam Pondok Pesantren. Khususnya para Santri yang akan mengikuti kegiatan pelatihan. Prosedur pengamatan di lapangan dilakukan sebagai berikut: 
A. Mendata identitas lokasi sebagai data administrasi.

B. Melakukan identifikasi sasaran peserta: mendata usia, jenis kelamin, pendidikan.

C. Mendata jadwal kegiatan rutin santri, agar dapat ditentukan waktu pelatihan yang tidak mengganggu jadwal mereka sehari-hari.

D. Mengumpulkan informasi jenis keterampilan yang dibutuhkan.

E. Mengumpulkan informasi dan mengamati sarana: tempat yang sesuai dengan kebutuhan aktifitas pelatihan.

F. Mengumpulkan informasi sumber bahan baku yang dapat dijadikan materi pelatihan.

Pada saat kunjungan ke lapangan, selain pengamatan juga dilakukan wawancara untuk memperoleh informasi pendukung dengan pimpinan Pondok Pesantren yaitu Ustaz Saiful Abror. Al-Banjari. Berdasarkan data lapangan dilakukan studi literatur melalui berbagai media, untuk menentukan jenis pelatihan dan metode penyampaian pelatihan.

Dari analisis data yang telah diperoleh maka ditentukan teknik penyampaian pelatihan melalui tahapan sebagai berikut:

A. Presentasi dengan materi tentang :

1. Latar belakang pentingnya pelestarian alam.

2. Mendorong untuk sadar lingkungan tentang pelestarian alam.

3. Potensi sumber daya manusia dan limbah yang ada di sekitar pondok pesantren.

4. Pengetahuandasartentangwarnadanprinsipdesain.

5. Teknik dan cara pengolahan limbah botol plastik

B. Praktek pembuatan limbah botol plastik menjadielemendekorasi.

Berdasarkan hasil pengamatan dan informasi, maka pelaksanaan pelatihan ditujukan kepada:

1. Santri dari Pondok Pesantren Raudhatul Ishlah.

2. Jenis kelamin laki-laki

3. Usia 14 tahun hingga 20 tahun

4. Pendidikan: SD, SMP, MTS, MAN

Selanjutnya setelah pelatihan, diharapkan para santri dapat menularkan pengetahuan dan keterampilan yang telah diperoleh kepada masyarakat di lingkungan sekitar pesantren maupun lingkungan rumah tempat tinggal asal para santri.
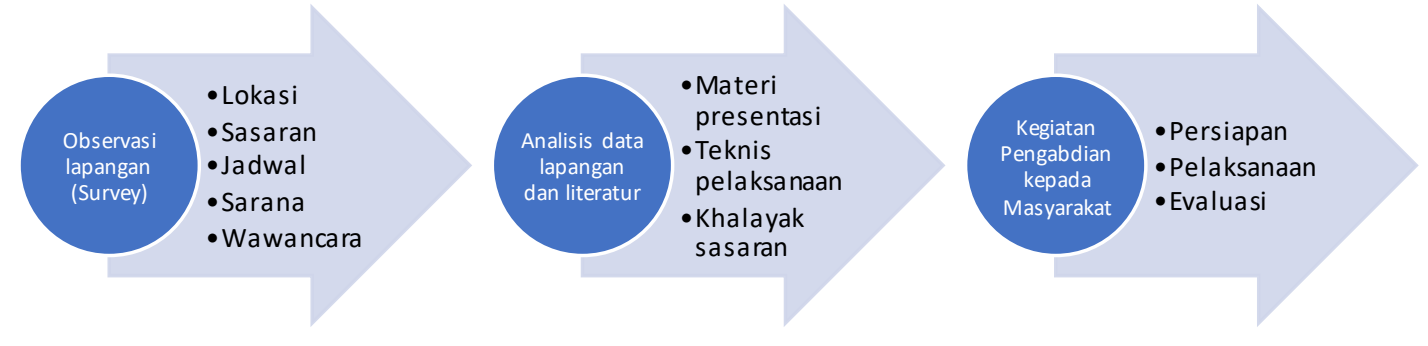

Gambar 1.Tahapan Kegiatan

\section{HASIL DAN PEMBAHASAN}

Kegiatan dilaksanakan di pendopo pondok pesantren Raudhatul Ishlah. Jl. Kemuning. Bukit Nusa Indah. Serua. Ciputat. Tangerang Selatan. Merupakan area terbuka di dalam komplek pondok pesantren yang terjaga kebersihannya serta sangat asri. Luas pesantren 
kurang lebih 2500 meter persegi, namun sebagian besar masih berupa ruang terbuka yang berbatasan dengan lahan kosong seluas 5000 meter persegi, sungai, komplek perumahan sehingga nyaman, terbuka dan relatif aman dari resiko penularan penyakit, khususnya Covid19.

Gā̄bar2. Sumber: Google Maps

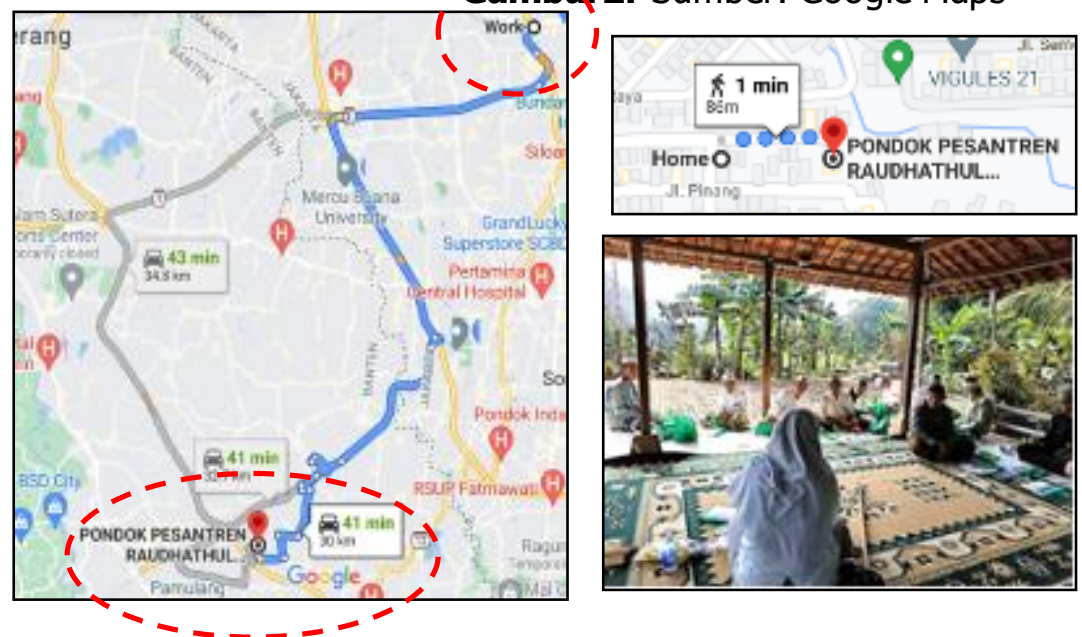

Lokasi pesantren dari tempat bekerja (Universitas Trisakti) berjarak 30 kilometer, dengan kendaraan pribadi, dapat dicapai dalam waktu 41 menit.Sedangkan dari kediaman ketua tim hanya berjarak 86 meter, dapat dicapai dengan berjalan kaki dalam waktu relatif singkat.

Kegiatan dilaksanakan pada pagi hari (mulai pukul 08.00) sampai dengan siang hari (pukul 12.00) yaitu waktu produktif para santri, serta dilakukan di area terbuka sehingga instruktur dan peserta sekaligus dapat memperoleh siraman sinar matahari yang menyehatkan dan mengurangi resiko penularan penyakit.
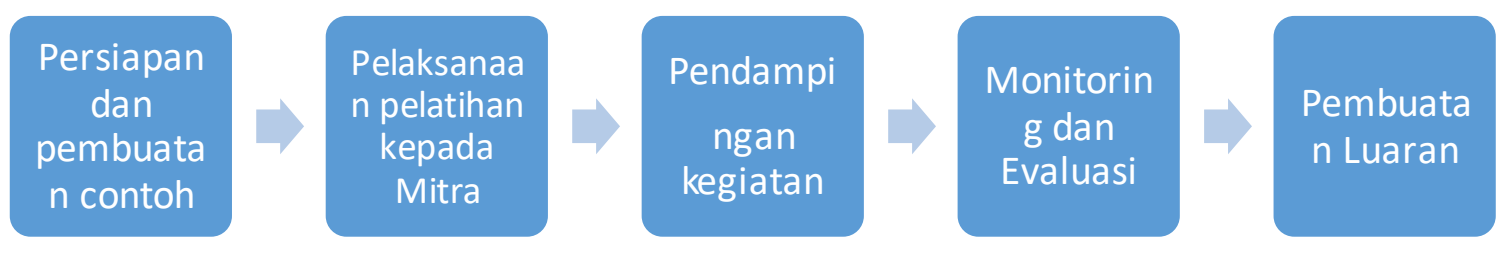

Gambar 3.Tahapan pelaksanaan, monitoring dan evaluasi

Tahapan kegiatan pelaksanaan di lapangan adalah:

1. Presentasi tim.

Diawali dengan paparan tentang teori warna dan prinsip desain, peserta dibagikan handout yang berisi materi paparan dan teknis praktek yang akan dilakukan kemudian. Setelah paparan teori, dilanjutkan dengan penjelasan teknis pelaksanaan disertai dengan contoh. Produk yang dibuat oleh peserta adalah membuat sapu dan wadah dari limbah botol plastik. 

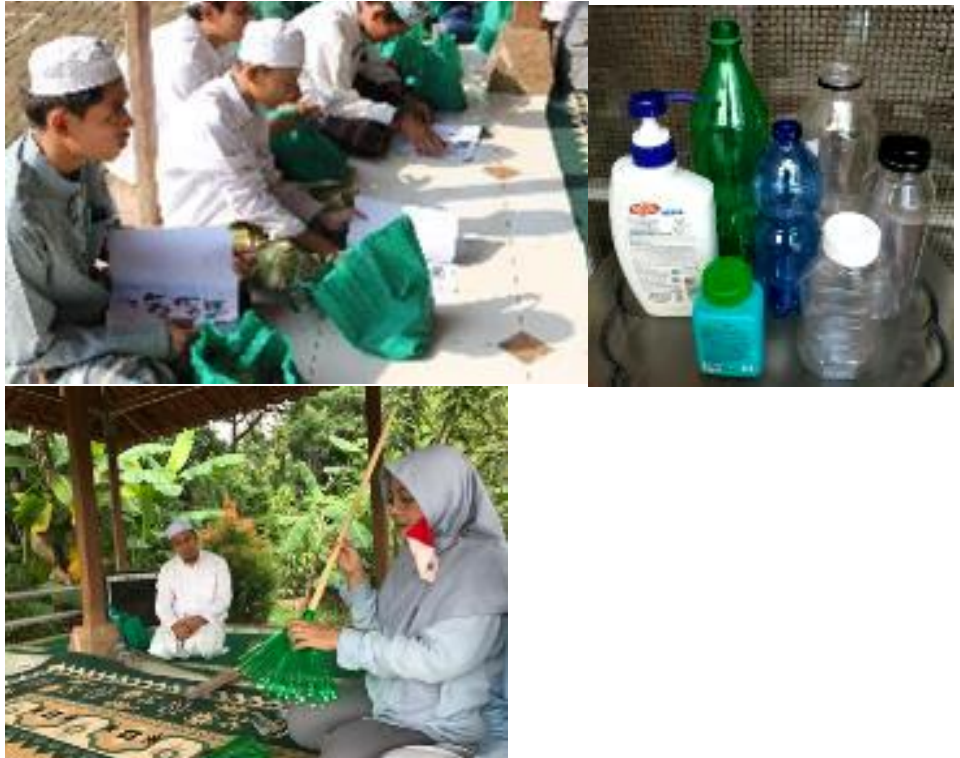

Gambar 4. Presentasi, contoh limbah botol plastik, dan produk yang akan dibuat oleh peserta.

Sumber: Dokumentasi pribadi

2. Praktek pembuatan produk oleh peserta.

Masing-masing peserta mencoba membuat produk berdasarkan paparan dan contoh yang telah disampaikan instruktur. Pelaksanaan mendapat bimbingan serta arahan dari para instruktur. Bimbingan diberikan berkaitan dengan presentasi, tahapan, ketelitian serta keamanan peserta pada saat menggunakan alat potong dan benda-benda tajam lainnya. Selama proses pengerjaan, tim PkM senantiasa mendampingi serta memberi petunjuk tahapan demi tahapan. Pada kegiatan ini partisipasi dari peserta menjadi kunci utama keberhasilan program pelatihan. Partisipasi adalah keterlibatan mental dan emosional sejumlah orang dalam suatu kegiatan atau situasi-situasi dan memberikan konstribusi terhadap kepentingan atau tujuan kelompok. Partisipasi dapat diwujudkan misalnya dalam bentuk menyumbangkan ide atau kritik, mengorganisasikan lingkungan, dan turut mengembangkan daya cipta (Purnomo, 2013 dalam Adisurya, 2021).

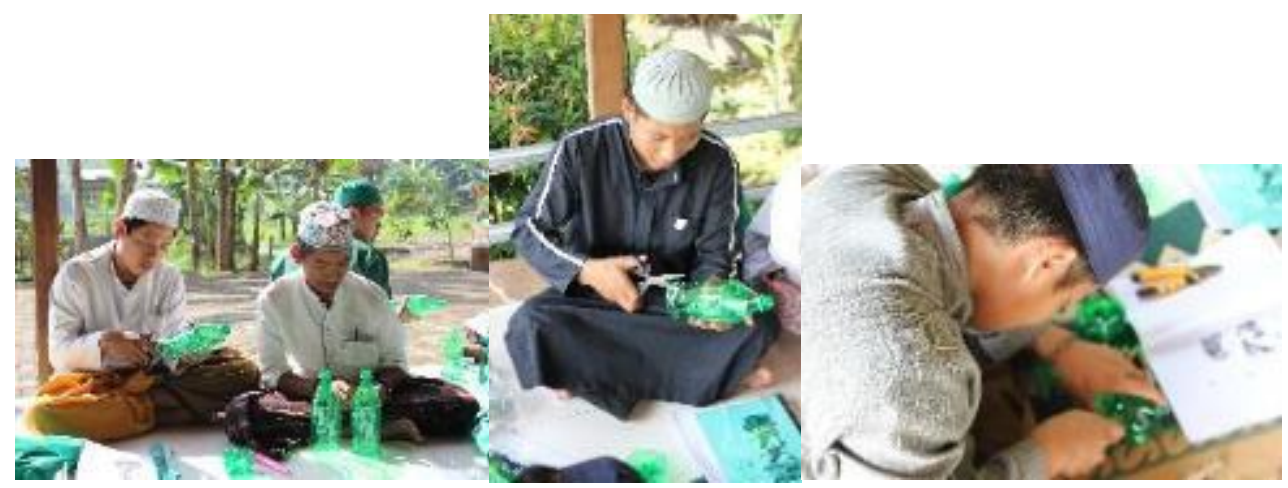

Gambar 5. Praktek pembuatan produk oleh peserta. Sumber: Dokumentasi pribadi 
3. Evaluasi hasil pelaksanaan program bersam apeserta.

Selesai pelatihan setiap peserta hadir bersama instruktur dengan produk yang telah dibuat. Instruktur memberikan koreksi, saran, dan arahan. Sedangkan peserta memberikan tanggapan baik secara lisan serta tertulis berupa kuesioner yang harus diisi oleh setiap peserta. Materi kuesioner adalah tentang: presentasi, pelaksanaan, kritik dan saran peserta terhadap pelaksanaan pelatihan.

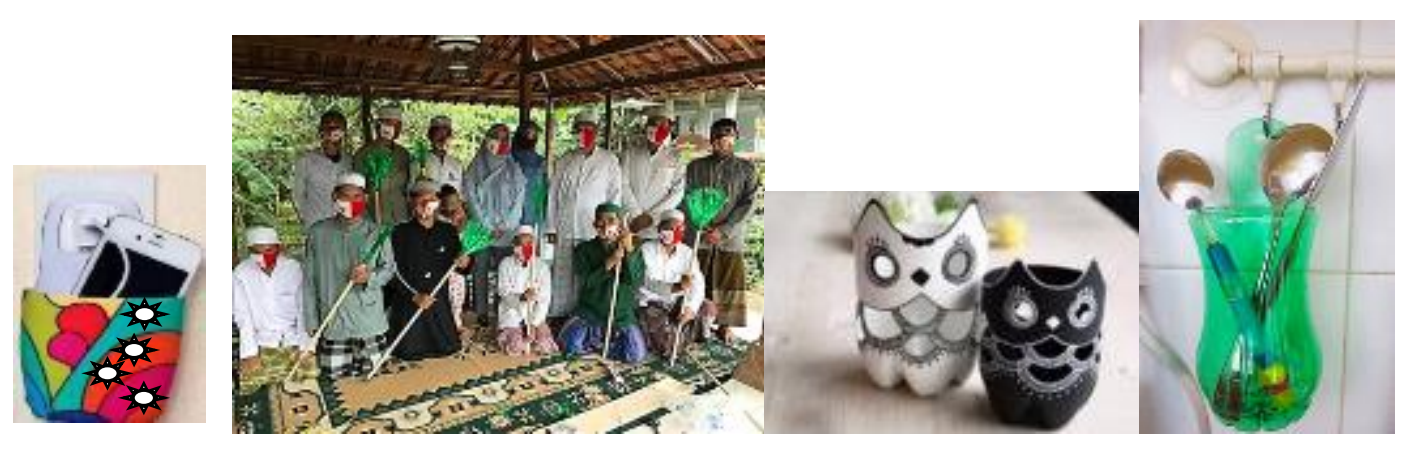

Gambar 6. Peserta dan instruktur dengan produk pelatihan. Sumber: Dokumentasi pribadi

Berdasarkan pelaksanaan yang telah dilakukan, terdapat faktor pendukung dan faktor penghambat:

1. Faktor pendukung:

a. Usia produktif (SDM/Sumber Daya Manusia tepat sasaran), sehingga keterampilan dapat dikuti dengan mudah, sesuai dengan hasil pengamatan saat praktik dan hasil angket. Peserta tertarik dan merasakan manfaatnya sehingga semangat dalam melaksanakan kegiatan dan berusaha membuat improvisasi dalam mengembangkan kreatifitas dalam karya masing-masing.

b. Lokasi pondok memiliki potensi untuk mengembangkan kreatifitas berupa limbah dan bahan alam sekitar seperti: bulu ayam/burung ternak, eceng gondok, pohon pisang, kelapa, bambu, ranting, akar dan berbagai unsure dari tanaman lainnya.

c. Lokasi dekat dengan tempat tinggal instruktur, tempat pelatihan terbuka, suasana asri. Sesuai dengan kebutuhan dalam kondisi pandemi.

d. Pimpinan pondok sejak awal sangat terbuka dan 'welcome' dengan program yang diajukan.

2. Faktor penghambat:

a. Faktor penghambat saat pelaksanaan hampir tidak ada, hanya pada wawasan peserta yang terbatas,

b. Pengembangan keterampilan di masa yang akan datang terkendala keterbatasan dana untuk bahan praktik,

c. Sarana untuk memperluas wawasan dengan media internet sangat kurang, karena sarana komputer di pondok hanya 1 (satu) buah para santri tidak memiliki HP, tidak ada wifi.

\section{SIMPULAN}

Berdasarkan hasil pengamatan dan analisis tim, maka kesimpulan dan saran pelaksanaan program adalah: 
1. Melalui pelatihan pemanfaatan limbah botol plastic menjadi produk siap pakai, peserta mendapat tambahan pengetahuan dan keterampilan sehingga para santri dapat mengembangkan dan meningkatkan kreatifitas.

2. Keterampilan dan pengetahuan tentang warna dan prinsip-prinsip desain yang diperoleh dapat membantu santri mengisi waktu luang dengan kegiatan yang bermanfaat sehingga lebih kreatif dan produktif.

3. Program dan keterampilan yang diberikan sudah tepat sasaran, karena produk dapat dikerjakan dengan baik dan cukup mudah. Produk yang dihasilkan juga sangat dibutuhkan danberfungsidenganbaik di pondok.

Hanya karena keterbatasan waktu, maka ketelitian dan kerapihan pekerjaan masih perlu ditingkatkan. Diharapkan akan ada program lanjutan dengan tingkat kesulitan, ketelitian, kreatifitas yang lebih tinggi dan alternatif material yang lebih variatif yang tinggidengan menerapkan prinsip-prinsip desain yang baik.

\section{DAFTAR PUSTAKA}

Adisurya, S., Ariani, Wilastrina, A., Wiemar, R. (2021). "Peningkatan Kreativitas Remaja Karang Taruna Dalam Membuat Hiasan Kepala dan Masker untuk Tari Betawi Kreasi". AKSARA: JurnalIImuPendidikanNonformal, 7 (2). DOI :10.37905/aksara.7.2.177-190.2021

Bahraini, Amanda (2019). " Waste4Change Mendukung Konsep Hijau 3R (Reduce-ReuseRecycle)". Diunduh tanggal: 11 Agustus 2021. Waste4Change, Waste Management. https://waste4change.com/blog/konsep-prinsip-3r-reduce-reuse-recycle/

Marwanza, I., Azizi, MA., Nas, C., dkk. (2021). "Pemanfaatan Briket Arang Tempurung Kelapa Sebagai Bahan Bakar Alternatif di Desa Banjar Wangi, Pandeglang, Provinsi Banten. AKAL:JurnalAbdimas dan Kearifan Lokal, 02(01), 82-88. DOI : 10.25105/akal.v2i1.9040

Pojok Gusmen. (2020) "Kemenag Petakan Kurikulum Pesantren". Diunduh tanggal: 11 Agustus 2021. Kementrian Agama Republik Indonesia. https://kemenag.go.id/berita/read/513885/berita

Staff Pusat Krisis Kesehatan (PKK). (2016). "Botol Plastik Bisa Menjadi Sumber Bencana Lingkungan". Diunduh tanggal 29 Oktober 2020. Kementerian Kesehatan Republik Indonesia. Pusat Krisis Kesehatan. https://pusatkrisis.kemkes.go.id/botol-plastik-bisamenjadi-sumber-bencana-lingkungan

Zulkarnain, A., Laurencia, J., Melini, E. (2021). "Pengembangan dan Pemberdayaan Masyarakat Pada Komunitas Sekolah Darussalam, Kelurahan Mekar Bakti, Kecamatan Panongan, Tangerang".AKAL:JurnalAbdimas dan Kearifan Lokal, 02 (01), 62-73. DOI : 10.25105/akal.v2i1.9038 